\title{
Severe anemia caused by the angiotensin receptor blocker irbesartan after renal transplantation
}

\author{
Giacomo D. Simonetti • Mario G. Bianchetti • \\ Martin Konrad • Rodo O. von Vigier
}

Received: 9 November 2006 / Revised: 14 November 2006 / Accepted: 14 November 2006 / Published online: 10 January 2007

(C) IPNA 2007

Renal transplant recipients are often anemic in the early post-engraftment period because of preexisting anemia exacerbated by perioperative blood loss [1]. Six or more months after transplantation, anemia is slightly less common, and mostly occurs in the setting of chronic allograft nephropathy associated with reduced glomerular filtration rate [1]. We report the first pediatric case of anemia after renal transplantation caused by the use of irbesartan, a drug that inhibits the renin-angiotensin II-aldosterone system by blocking the type 1 of angiotensin II receptors [2-5].

A 12-year-old boy with a history of congenital nephrotic syndrome of the Finnish type and poor renal function (GFR estimated $25 \mathrm{ml} / \mathrm{min} / 1.73 \mathrm{~m}^{2}$, urinary protein/creatinine ratio $48 \mathrm{mg} / \mathrm{mmol}$ ) 7 years after a cadaveric transplantation was on treatment with the immunosuppressants mycophenolate and sirolimus. This rather unusual immunosuppressive regimen had been started 2 years earlier because of resistant arterial hypertension and chronic nephropathy while on therapy with cyclosporine A, azathioprine and prednisone. The chronic antihypertensive regimen included

Giacomo D. Simonetti is currently supported by a scholarship of the Ettore e Valeria Rossi Foundation.

G. D. Simonetti $\cdot$ M. Konrad $\cdot$ R. O. von Vigier

Department of Pediatrics, Division of Pediatric Nephrology, Inselspital,

Bern, Switzerland

M. G. Bianchetti

Ospedale Mendrisio and Bellinzona,

Bellinzona, Switzerland

G. D. Simonetti $(\bowtie)$

Pediatric Nephrology, Kinderklinik, Inselspital,

3010 Bern, Switzerland

e-mail: giacomo.simonetti@insel.ch the calcium-channel blocker amlodipine $(0.16 \mathrm{mg} / \mathrm{kg}$ body weight once a day), the $\beta$-blocker metoprolol $(1.7 \mathrm{mg} / \mathrm{kg}$ body weight once a day) and irbesartan (up to $10 \mathrm{mg} / \mathrm{kg}$ body weight once a day). An important hyporegenerative normocytic anemia (hemoglobin $63 \mathrm{~g} / \mathrm{l}$ ) was noted, which was not associated with either acute or chronic infections, including testing for Parvovirus B19 infection, and failed to improve on parenteral iron and recombinant human erythropoietin (at the beginning $170 \mathrm{IU} / \mathrm{kg}$ weekly, increased during anemia up to $230 \mathrm{IU} / \mathrm{kg}$ weekly). Finally, hemoglobin increased up to $119 \mathrm{~g} / 1$ within 4 weeks after withdrawing irbesartan (Fig. 1).

Drugs that inhibit the renin-angiotensin II-aldosterone system modestly decrease hemoglobin and circulating erythropoietin [1]. Like converting enzyme inhibitors, angiotensin II receptors blockers may produce anemia either by direct inhibition of erythropoietin or insulin-like growth factor-1 production, or via an indirect mechanism that improves renal perfusion and subsequently decreases oxygen consumption. Furthermore, a negative effect on hematopoiesis at the bone-marrow level has also been suggested, since angiotensin II type 1 receptors have been identified on erythroid progenitors [6].

The effect on hemoglobin is usually of limited clinical relevance, and should not stand in the way of use of these agents for their cardioprotective and renoprotective effects $[1,2]$. The present report confirms that there may be "susceptible" patients for whom hemoglobin levels decrease significantly on drugs that inhibit the renin-angiotensin II-aldosterone system [1]. Thus, in selected cases, some thought could be given to engineering a "drug holiday" to test whether hemoglobin level increases after discontinuation, as previously reported in a child with nephrotic syndrome on treatment with the converting enzyme inhibitor enalapril [7]. 


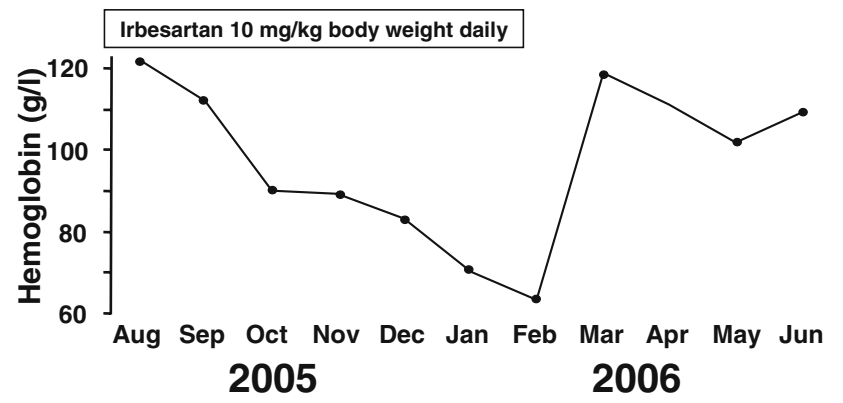

Fig. 1 Hemoglobin levels with and without irbesartan, a drug that inhibits the renin-angiotensin II-aldosterone system by blocking the type 1 of angiotensin II receptors

\section{References}

1. Afzali B, Al-Khoury S, Shah N, Mikhail A, Covic A, Goldsmith D (2006) Anemia after renal transplantation. Am J Kidney Dis 48:519-536
2. Karalliedde J, Viberti G (2006) Evidence for renoprotection by blockade of the renin-angiotensin-aldosterone system in hypertension and diabetes. J Hum Hypertens 20:239-253

3. Gartenmann AC, Fossali E, von Vigier RO, Simonetti GD, Schmidtko J, Edefonti A, Bianchetti MG (2003) Better renoprotective effect of angiotensin II antagonist compared to dihydropyridine calcium channel blocker in childhood. Kidney Int 64:14501454

4. Yim HE, Kim MK, Bae IS, Kim JH, Choi BM, Yoo KH, Hong YS, Lee JW (2006) AT1 antagonist modulates activin-like kinase 5 and TGF-beta receptor II in the developing kidney. Pediatr Nephrol 21:1377-1388

5. Rossing K, Schjoedt KJ, Jensen BR, Boomsma F, Parving HH (2005) Enhanced renoprotective effects of ultrahigh doses of irbesartan in patients with type 2 diabetes and microalbuminuria. Kidney Int 68:1190-1198

6. Ersoy A, Kahvecioglu S, Ersoy C, Cift A, Dilek K (2005) Anemia due to losartan in hypertensive renal transplant recipients without posttransplant erythrocytosis. Transplant Proc 37:21482150

7. Sackey AH (1998) Anaemia after enalapril in a child with nephrotic syndrome. Lancet 352:285-286 